\title{
Article 3. Scope
}

This Protocol shall apply to genetic resources within the scope of Article 15 of the Convention and to the benefits arising from the utilization of such resources. This Protocol shall also apply to traditional knowledge associated with genetic resources within the scope of the Convention and to the benefits arising from the utilization of such knowledge.

Overview

This short provision ${ }^{1}$ aims to clarify the ambit of application of the Protocol: it, however, only addresses its subject-matter scope and it does so in a rather obscure manner. Several other scope-related issues, notably the temporal and spatial scope of the Protocol, were heavily debated during the negotiations but were eventually not explicitly addressed in its final text.

Article 3 at least implicitly clarifies that ${ }^{2}$ the Protocol applies not only to access to and benefit-sharing from the utilization of genetic resources, but also to traditional knowledge associated with genetic resources. And the Article appears to draw a distinction between the scope of application related to genetic resources and to traditional knowledge.

The following sections will discuss the ambiguity in the delineation of the subject-matter scope of the Protocol and analyze outstanding questions related to its temporal and spatial scope. It should also be noted that other Articles in the Protocol contribute to defining its scope. ${ }^{3}$

1 The text reproduces the final compromise proposal of the Japanese cop10 Presidency, which closely follows the text of draft article 3 in the Cali Draft. The only modification was the insertion of an explicit reference to the 'scope of Article 15' of the Convention in relation to genetic resources.

2 As opposed to what can be inferred from the title of the Protocol and its Article 1: see this commentary on Article 1, section 3.

3 See, e.g., this commentary on Articles 2,4 and 8.

(C) Elisa Morgera, Elsa Tsioumani, and Matthias Buck, 2015.

This is an open access chapter distributed under the terms of the Creative Commons Attribution-Noncommercial 3.0 Unported (CC-BY-NC 3.0) License. 
Article 3 appears to distinguish between the scope of the Protocol in relation to genetic resources, which is delimited by a specific reference to Article 15 of the Convention, and the scope in relation to traditional knowledge, which refers to the general scope of Convention.

With regards to traditional knowledge, however, it is difficult to understand what the Nagoya Protocol intends by making a general reference to the Convention, as its text is silent on 'traditional knowledge associated with genetic resources' ${ }^{4}$ With regards to genetic resources, the specific reference to СвD Article 15 is equally puzzling, as that Article does not address questions related to subject-matter scope, but simply reaffirms Parties' rights to regulate access to genetic resources under their national jurisdiction through national law. ${ }^{5}$ The only possible explanation for the obscure drafting of Article 3 can be traced back to the negotiators' intention to de-link the spatial scope of the Nagoya Protocol in relation to genetic resources from the СвD provision on jurisdictional scope. The latter states that the Convention applies to processes and activities under Parties' jurisdiction or control also in areas beyond the limits of national jurisdiction. ${ }^{6}$ Basically, the Protocol drafters' main concern was to implicitly exclude bioprospecting activities on marine genetic resources in areas beyond national jurisdiction from the scope of the Protocol, as discussed below.

As the overall usefulness of Article 3 of the Protocol is questionable, it will fall on the Protocol's governing body ${ }^{7}$ to clarify any questions on subjectmatter scope that may arise in the future.

\subsection{Human Genetic Resources}

Although the text of the Convention is silent about human genetic resources, СвD Parties adopted Decision 2/11 stating that human genetic resources are not included within the framework of the Convention. ${ }^{8}$ Negotiators debated

4 As explained in the Introduction in this commentary, section 3, there is no explicit link between traditional knowledge and genetic resources in the text of the Convention.

5 СвD Article 15(1) reads: 'Recognizing the sovereign rights of States over their natural resources, the authority to determine access to genetic resources rests with the national governments and is subject to national legislation.'

6 свD Article 4(b). See also Buck and Hamilton, "Nagoya Protocol," op. cit., 57.

7 Nagoya Protocol Article 26(4)(a). See this commentary on Article 26, section 2.

8 See свD Decision 2/11, "Access to genetic resources" (30 November 1995) UN Doc UNEP/ СвD/COP/2/19, paragraph 2 . 
whether to explicitly exclude human genetic resources from the Protocol's scope ${ }^{9}$ but eventually decided against such an explicit reference. However, СвD Parties, when adopting the Protocol, recalled Decision 2/11 and restated that human genetic resources are not included within the framework of the Protocol, noting that this decision was without prejudice to further consideration of the issue by its governing body. ${ }^{10}$

\section{$3 \quad$ Outstanding Questions}

The Protocol is silent on questions related to temporal and spatial scope, although these were heavily debated in the negotiations. Other questions addressed in that context related to the relationship between the Protocol and other international treaties and processes, ${ }^{11}$ that will be discussed in the sections of this commentary concerning Articles 4 (Relationship with International Agreements and Instruments) and 8 (Special Circumstances). The following sub-sections will focus on outstanding questions related to the temporal and spatial scope.

\subsection{Temporal Scope}

As regards temporal scope, ${ }^{12}$ the Protocol clearly applies to genetic resources and traditional knowledge associated with such resources utilized after the entry into force of the Protocol for a Party. Negotiators, however, had discussed whether the Protocol should address more complex questions related to genetic resources and traditional knowledge acquired after the entry into force of the Convention but before the entry into force of the Protocol. The argument was put forward by developing countries. They argued that the international obligation to share benefits and obtain informed consent prior to access pre-existed the Protocol, as it was already included under the Convention. ${ }^{13}$

$9 \quad$ See Montreal I Draft, draft article 3.

10 СвD Decision 10/1, paragraph 5.

11 See references to the ITPGRFA and to human pathogens in Montreal I Draft, draft article 3.

12 Tvedt and Young, Beyond Access, op. cit., 14, note some of the uncertainties that already existed regarding the temporal coverage of свр Article 15.

13 See submissions by Namibia on behalf of the African Group to the CBD Working Group on ABs, "Collation of operative text submitted by Parties, governments, international organisations, indigenous and local communities and relevant stakeholders in respect of the main components of the international regime on access and benefit-sharing listed in Decision IX/12, Annex I" (28 January 2009) Un Doc UnEP/CвD/WG-ABs/7/4, paragraphs $11-12$. 
They further argued that the benefit-sharing obligation in СвD Article 15(7) is independent from the creation of national ABs frameworks and the establishment of мAт. ${ }^{14}$ They thus proposed that the benefit-sharing obligation of the Protocol apply to new and continuing uses of genetic resources and traditional knowledge acquired after the entry into force of the Convention (but before the Protocol's entry into force), under 'modified procedures for benefit-sharing' to be developed by the Protocol's governing body. ${ }^{15}$ This, it was argued, would not constitute a retroactive application of the Protocol since the focus would be on new facts. ${ }^{16}$ The underlying rationale of the proposal was to expand the range of situations in which the benefit-sharing obligations of the Protocol would apply, and to address possible loopholes related to ex situ collections already existing in developed countries' genebanks. The proposal encountered firm opposition from most developed countries, who wished instead to explicitly exclude 'genetic resources and traditional knowledge associated with genetic resources acquired prior to the entry into force of the Protocol.17 A compromise proposal was then put forward by Norway and the African Group to at least create an obligation for States to encourage individual users to take all

14 ENB 9/527, "Summary of the Resumed Ninth Meeting of the Working Group on ABs," 5. An argument can be made that, because Article 15(7) is clearly worded, unconditional and framed in unequivocally legally binding terms, it could be self-executing. This point remains contentious: see Tvedt and Young, Beyond Access, op. cit., 2 and fn. 9.

15 СвD Working Group on ABS, "Report of the first part of the ninth meeting," UNEP/CBD/ WG-ABs/9/3, paragraph 119; and Montreal I Draft, draft article 3.

16 See Singh Nijar and Pei Fern, Nagoya ABs Protocol, op. cit., 26; and Evanson C. Kamau, Bevis Fedder and Gerd Winter, "The Nagoya Protocol on Access to Genetic Resources and Benefit Sharing: What Is New and What Are the Implications for Provider and User Countries and the Scientific Community?," Law, Environment and Development Journal 6 (2010): 246, 255, where the authors argue that 'Clearly, this means that any genetic resource or traditional knowledge accessed before [entry into force of the Protocol] cannot retroactively be made subject to PIC requirements. Likewise, any benefits obtained before that date cannot retroactively be subjected to a benefit-sharing obligation. However, it can be argued that the generation of benefits after that date is a new act in terms of Article 28 of the Vienna Convention, or that the holding of the genetic resource or traditional knowledge is a situation which has not ceased to exist.' See also Berne Declaration and Natural Justice, Access or Utilization - What Triggers User Obligations? A Comment on the Draft Proposal of the European Commission on the Implementation of the Nagoya Protocol on Access and Benefit Sharing (Cape Town and Zurich: Berne Declaration and Natural Justice, 2013), accessed 1 November 2013, <http://naturaljustice.org/wpcontent/uploads/pdf/Submission-EU-ABS-Regulation.pdf>, 6-8. СвD/Сор/10/5/ADD.4, paragraph 133; and Montreal I Draft, draft article 3. 
reasonable measures to enter into benefit-sharing arrangements with a country of origin for new and continuous utilization of genetic resources acquired before the entry into force of the Protocol. ${ }^{18}$ None of these proposals, however, made it in the final text of the Nagoya Protocol.

As a result, issues related to temporal scope are not specifically addressed by the text of the Protocol. ${ }^{19}$ Nevertheless, some commentators have argued that while the Protocol does not apply to genetic resources acquired prior to the entry into force of the $\mathrm{CBD}$, it does not prevent Parties from requiring, in their domestic ABs frameworks, benefit-sharing arising from new and continuing uses of genetic resources acquired after the entry into force of the Convention but before the entry into force of the Protocol. ${ }^{20}$ Equally, the text of the Protocol does not exclude that Parties may require benefit-sharing arising from new and continuing uses of traditional knowledge acquired prior to the entry into force of the Protocol. ${ }^{21}$ Others, instead, exclude both possibilities, arguing that the main operational provisions of the Protocol refer to genetic resources provided by a Party to the Protocol on the basis of its domestic ABs framework. ${ }^{22}$

It may be tentatively concluded that the Protocol does not apply to genetic resources acquired prior to the entry into force of the Convention, ${ }^{23}$ but it remains debatable whether benefit-sharing obligations arise under the Protocol for new or continuing uses of genetic resources acquired in the interim period between the entry into force of the СвD and that of the Protocol. As the Protocol is silent on these complex questions, it appears that an interpretative decision or guidance reached by the Protocol Parties collectively through

18 See Montreal I Draft, draft article 3, second last paragraph. A similar proposal on traditional knowledge in draft article 9(5) of the Cali Draft was also deleted in the final compromise proposal. свр Working Group on Aвs, "Report of the second part of the ninth meeting," UNEP/CBD/COP/10/5/ADD.4, paragraph 133.

19 VCLT Article 28 reads: 'Unless a different intention appears from the treaty or is otherwise established, its provisions do not bind a Party in relation to any act or fact which took place or any situation which ceased to exist before the date of the entry into force of the treaty with respect to that Party.'

$20 \quad$ Greiber et al, Explanatory Guide, op. cit., 72-73.

21 Ibid., 90.

22 Buck and Hamilton, "Nagoya Protocol," op. cit., 57, making reference to Nagoya Protocol Articles 5-6 and 15.

23 The Protocol reference to 'genetic resources within the scope of Article 15 of the Convention' presupposes the existence of a Party to the Convention, i.e., that the Convention has entered into force. That being said, the possibility cannot be excluded that this discussion may be reopened in the context of Nagoya Protocol Article 10: see below in this section. 
the Protocol's governing body ${ }^{24}$ on how to address new and continuing uses would be desirable. This is particularly critical as practical and legal problems could arise if different Parties were to base their domestic ABs frameworks on different understandings of the temporal scope. ${ }^{25}$ To name but a few of such problems, pre-Nagoya Protocol decisions on PIC and MAT may not conform with the Protocol requirements; no internationally recognized certificate of compliance would exist; or users may have already obtained intellectual property rights on material and innovations developed on the basis of genetic resources acquired in good faith before the entry into force of the Protocol. The status of ex situ collections pre-dating the entry into force of the Protocol may be also addressed by the Protocol's governing body in this context. These discussions could also be (and actually have already been) ${ }^{26}$ entertained in relation to a possible global benefit-sharing mechanism under the Protocol. ${ }^{27}$ The absence of a collective solution on the temporal scope could possibly lead to a situation in which the Protocol's compliance procedures and mechanisms ${ }^{28}$ would be used to consider whether lack of implementing measures in a user Party taking a restrictive approach to the question of the temporal scope, that does not support the benefit-sharing claims of a provider Party taking a broader approach to the temporal scope with regard to new uses of material accessed before the Protocol's entry into force, would constitute non-compliance.

24 Nagoya Protocol Article 26(4)(a).

25 For example, the draft EU regulation for implementing the Nagoya Protocol in the EU would explicitly apply to genetic resources accessed after the entry into force of the Nagoya Protocol for the Union, with the term 'access' defined as 'the acquisition of genetic resources or traditional knowledge associated with genetic resources in a Party to the Nagoya Protocol' (emphasis added): European Commission, Proposal for a Regulation of the European Parliament and of the Council on Access to Genetic Resources and the Fair and Equitable Sharing of Benefits Arising from their Utilization in the Union, сом(2012) 576 final, (hereinafter, EU draft regulation), draft article 2.1.

26 "Draft decision for the consideration of the first meeting of the Conference of the Parties Serving as the Meeting of the Parties to the Nagoya Protocol," in ICNP, "Report of the second meeting of the Open-ended Ad Hoc Intergovernmental Committee for the Nagoya Protocol on Access to Genetic Resources and the Fair and Equitable Sharing of Benefits Arising from Their Utilization," (26 July 2012), un Doc UNEP/CbD/cop/11/6, Annex, section $2 / 3$, where specific reference is made to issues related to ex situ conservation. See also EnB, "Summary of the Second Meeting of the Intergovernmental Committee for the Nagoya Protocol on Access and Benefit-sharing to the Convention on Biological Diversity: 2-6 July 2012," Vol. 9 No. 579, 9 July 2012, 10.

27 See this commentary on Article 10, section 2.2.

28 See this commentary on Article 30. 


\subsection{Spatial Scope}

The negotiators also considered whether the Protocol should only apply to genetic resources over which Parties exercise sovereign rights, and thus whether to include or exclude explicitly from its scope genetic resources from beyond areas of national jurisdiction. The latter include genetic resources located in marine areas beyond the limits of national jurisdiction (the high seas $^{29}$ and the Area $)^{30}$ or the Antarctic Treaty Area. ${ }^{31}$

With regard to marine genetic resources located beyond national jurisdiction, the reference to СвD Article 15 in the Protocol arguably serves to emphasize genetic resources over which States exercise sovereign rights and implicitly indicate the negotiators' intention to de-link the spatial scope of the Nagoya Protocol from CBD Article 4(b). This would suggest that bioprospecting for genetic resources in areas beyond national jurisdiction does not fall under the scope of the Nagoya Protocol. ${ }^{32}$ Whether this is indeed the case,

29 UNCLOS Part VII.

30 The Area is 'the sea-bed and ocean floor and subsoil thereof, beyond the limits of national jurisdiction' (UNCLOS Article 1(1)(1)). UnCLOS Part XI and Agreement relating to the Implementation of Part XI of the United Nations Convention on the Law of the Sea (New York, 28 July 1994, in force 28 July 1996) 1836 unTs 3.

31 See references to excluding or specifically inducing in the scope 'genetic resources located in the Antarctic Treaty Area, which is the area south of latitude $60^{\circ}$ South,' 'genetic resources beyond national jurisdictions' and 'genetic resources from marine areas beyond national jurisdiction' in Montreal I Draft, draft article 3, which foresaw (in case of inclusion in the scope) a mandate for the Protocol's governing body to adopt modified procedures for benefit-sharing for genetic resources. For a discussion of this specific issue, see СвD Working Group on ABs, "Study on the relationship between an international regime on access and benefit-sharing and other international instruments and forums that govern the use of genetic resources. The Antarctic Treaty System (ATS) and the United Nations Convention on the Law of the Sea (UNCLOS). Note by the Executive Secretary" (3 March 2009) un Doc UneP/CbD/Wg-Abs/7/Inf/3/Part3; Patrizia Vigni, "Antarctic Bioprospecting: Is It Compatible with the Value of Antarctica as a Natural Reserve?" in Francioni and Scovazzi, Biotechnology and International Law, op. cit., 111; Morten W. Tvedt, "Patent Law and Bioprospecting in Antarctica," Polar Record 47 (2011): 46; and Dagmar Lohan and Sam Johnston, The International Regime for Bioprospecting. Existing Policies and Emerging Issues for Antarctica (Tokyo: United Nations University Institute of Advanced Studies, 2003).

32 In favour of this interpretation: Buck and Hamilton, "Nagoya Protocol," op. cit., 57; Veit Koester, The Nagoya Protocol on ABs: Ratification by the EU and Its Member States and Implementation Challenges (Paris, France: IDDRI, 2012), accessed 30 November 2013, $<$ www.iddri.org/Publications/Collections/Analyses/STUDY0312_VK_nagoya\%20abs. pdf>, 16-17; Charlotte Salpin, "The Law of the Sea: A before and an after Nagoya?" in 
however, remains debatable, ${ }^{33}$ as ultimately the Protocol (and the СвD provision referred to in this context) are silent on this complex question and a clear determination on this issue is needed at the multilateral level. It cannot thus be excluded that the Nagoya Protocol's governing body may consider the matter explicitly in the future. This may well be the case depending on progress or lack thereof in ongoing discussions ${ }^{34}$ on marine biodiversity in areas beyond national jurisdiction under the UN General Assembly. ${ }^{35}$ It should in fact be emphasized that at the time of writing, discussions under the General Assembly have not reached the stage of formal intergovernmental negotiations on that matter. ${ }^{36}$ An interpretative decision or guidance by the Protocol's

Morgera, Buck and Tsioumani, 2010 Nagoya Protocol on Access and Benefit-Sharing in Perspective, op. cit., 149, 177; and Greiber et al., Explanatory Guide, op. cit., 73.

33 Sebastian Oberthür and Justyna Pozarowska, "The Impact of the Nagoya Protocol on the Evolving Institutional Complex of ABS Governance," in Oberthür and Rosendal, Global Governance of Genetic Resources, op. cit., 178, 188, conclude that the 'the situation of the geographical scope of the Nagoya Protocol remains ambiguous and it should in any event be difficult to oppose the notion of mutual supportiveness.' On mutual supportiveness between the Protocol and a future instrument on marine genetic resources in areas beyond national jurisdiction, see this commentary on Article 4, section 3.3.

34 UN General Assembly, "Oceans and the Law of the Sea" (2005) Un Doc A/REs/59/24, paragraph 73.

35 For a discussion of the possible interactions between the UN General Assembly and the Nagoya Protocol, see Salpin, "Law of the Sea," op. cit., 179-182.

36 In the context of the Ad Hoc Open-ended Informal Working Group to study issues relating to the conservation and sustainable use of marine biological diversity beyond areas of national jurisdiction, under the authority of the UN General Assembly. At its fourth meeting in 2011 the Working Group concluded that 'A process be initiated, by the General Assembly, with a view to ensuring that the legal framework for the conservation and sustainable use of marine biodiversity in areas beyond national jurisdiction effectively addresses those issues by identifying gaps and ways forward, including through the implementation of existing instruments and the possible development of a multilateral agreement under the United Nations Convention on the Law of the Sea': UN General Assembly, "Letter dated 30 June 2011 from the Co-Chairs of the Ad Hoc Open-ended Informal Working Group to the President of the General Assembly" (30 June 2011) UN Doc A/66/119, Annex, paragraph 1(a). At its sixth meeting in 2013, the Working Group decided 'to establish a process within the Working Group to prepare for a decision by the General Assembly before the end of its sixty-ninth session on marine biodiversity in areas beyond national jurisdiction, including by taking a decision on the development of an international instrument under unCLOS.' un General Assembly, 'Letter dated 23 September 2013 from the Co-Chairs of the Ad Hoc Open-ended Informal Working Group to the President of the General Assembly," (23 September 2013) un Doc A/68/399, Annex, paragraph 9. 
governing body ${ }^{37}$ may thus become necessary, particularly if the discussions under the General Assembly do not make significant progress by the time the Nagoya Protocol comes into force. In that regard, it may also be possible that Parties may decide to address some of this and the other above-mentioned questions in the context of the possible multilateral benefit-sharing mechanism under Article 10.38

37 Nagoya Protocol Article 26(4)(a): see this commentary on Article 26, section 2.

38 As a situation where it is not possible to grant or obtain PIC for the use of genetic resources: see this commentary on Article 10, section 2.2. Note that for those arguing that marine genetic resources beyond national jurisdiction fall outside the scope of the Nagoya Protocol, consideration of marine genetic resources in areas beyond national jurisdiction in the context of a possible multilateral benefit-sharing mechanism would require renegotiating the scope of the Protocol: Salpin, "Law of the Sea," op. cit., 177-179. The question has been put on the agenda of the first meeting of the Parties to the Protocol: see "Draft Decision for the consideration of the first meeting of the Conference of the Parties Serving as the Meeting of the Parties to the Nagoya Protocol," in ICNP, "Report of the second meeting of the Open-ended Ad Hoc Intergovernmental Committee for the Nagoya Protocol on Access to Genetic Resources and the Fair and Equitable Sharing of Benefits Arising from Their Utilisation," (26 July 2012) Un Doc Unep/CbD/Cop/11/6, Annex, Recommendation 2/3. 